\title{
APPLICATION OF THE FEDERAL ABSTENTION DOCTRINES TO THE DOMESTIC RELATIONS EXCEPTION TO FEDERAL DIVERSITY JURISDICTION
}

Despite the broad constitutional ${ }^{1}$ and statutory ${ }^{2}$ provisions granting federal diversity jurisdiction, the judiciary ${ }^{3}$ has created an exception to diversity jurisdiction for domestic relations actions. ${ }^{4}$ The federal courts have traditionally refused to entertain any action that involves divorce, child custody, or alimony, even if the case meets the statutory requisites for diversity jurisdiction. 5 The rationale underlying this judge-made exception has undergone significant transformation in recent years. ${ }^{6}$

1. U.S. ConST. art. III, § 2 provides:

The judicial Power shall extend to all Cases, in Law and Equity, arising under this Constitution, the Laws of the United States, and Treaties made, or which shall be made, under their Authority;- - to all Cases affecting Ambassadors, other public Ministers and Consuls; - to all Cases of admiralty and inaritime Jurisdiction;-to Controversies to which the United States shall be a Party;--to Controversies betweeu two or nore States;- - between a State and Citizens of another State;--betweeu Citizens of different States;-between Citizens of the same State claiming Lands imder Grants of different States, and between a State, or the Citizens thereof, and foreign States, Citizens or Subjects.

2. 28 U.S.C. \& 1332(a) (1976) provides, in relevant part, that the federal "district courts shall have original jurisdiction of all civil actions where the nuatter in controversy exceeds the sum or value of $\$ 10,000$, exclusive of interest and costs, and is between . . citizens of different States." Originally, the Cougressional grant of diversity jurisdiction extended to: (a) a suit of civil nature at common law or in equity in which there was (b) over $\$ 500$ in dispute, and which was (c) a suit between a citizen of the forum state and a citizen of another state. Judiciary Act of 1789, ch. 20, $\S 11,1$ Stat. 73, 78.

3. The Supreine Court has held that the actual extent of diversity jurisdiction is to be determined by judicial interpretation of the statutory grant. See, e.g., Kline v. Burke Constr. Co., 260 U.S. 226, 233-34 (1922); Turner v. Bank of N. Am., 4 U.S. (4 Dall.) 8, 11 (1799).

4. See generally P. Bator, P. Mishkin, D. Shapiro, \& H. Wechsler, Hart and Wechsler's The Federal Courts and the Federal System $1186-92$ (2d ed. 1973) [hereinafter cited as HART \& WECHSLER]. There is also an exception to federal diversity jurisdiction for probate matters. See generally Vestal \& Foster, Implied Limitations on the Diversity Jurisdiction of Federal Courts, 41 MiNN. L. Rev. 1, 13-23 (1956).

5. The rationale underlying the exception has also been extended to donestic relations actions in which jurisdiction is based upon the presence of a federal question. See infra notes 13665.

6. See, eg., Huynh Thi Anh v. Levi, 586 F.2d 625, 632 (6th Cir. 1978) ("While older cases indicate that federal courts are entirely without jurisdiction to grant divorces or award custody of children, more recent decisions hold that strong policies of federal-state counity and deference to state expertise in the area are the theoretical underpinnings of federal courts' refusal to consider such cases."). Compare Linscott v. Linscott, 98 F. Supp. 802, 805 (S.D. Iowa 195I) (The "term 
This note explores the history of the domestic relations exception, the abandonment of the origmal statutory rationale, and the subsequent establishment of a new rationale based on federalism and judicial economy. The note surveys the decisions applymg this new rationale and argues that, absent a statutory limitation on the exercise of federal jurisdiction, the domcstic relations exception should be viewed as a form of federal court abstention; that the standards employed in the abstention doctrimes should also be applied to domestic relations actions; and that the Supreme Court has either specifically rejected, or never accepted, many of the policy factors considered by courts applying the domestic relations exception.

The note then reviews the abstention doctrimes and applies the standards and principles found in these doctrines to domestic relations actions. The note argues that abstention is appropriate im a domestic relations action only: (1) when the litigants are seeking a divorce, child custody, or alimony decree and there is an element of unsettled state law; (2) when there is a concurrent state proceedimg mvolving peculiarly local factors; or (3) when a state court has already granted a modifiable divorce, child custody, or alimony dccree, and federal court review would require determination of present or future obligations under that decree.

\section{Transformations: The Nineteenth Century Through THE PRESENT}

\section{A. Origins of the Exception.}

The domestic relations exception to diversity jurisdiction origmated in dicta im two Supreme Court decisions in the nimeteenth century, Barber v. Barber ${ }^{7}$ and In Re Burrus. ${ }^{8}$ In Barber, the Court held that a fcderal district court had jurisdiction im a suit to enforce an existing separation and alimony decree by a wife living in New York agamst her husband, a resident of Wisconsm. The Court prefaced its opinion, however, by disclaiming federal jurisdiction altogether in orig-

'domestic relation' is to be given a broad liberal construction") and $1 \mathrm{~W}$. BARRON \& A. Holtzoff, Federal. Practice and Procedure § 40.1 (Wright ed. 1960) (The "lower courts have applied the principle more broadly, however, and will not take jurisdiction of cases which can be labelled as 'domestic relations' cases even where only property rights are involvcd"), with Sutter v. Pitts, 639 F.2d 842, 843 (1st Cir. 1981) (stating that the exception has been "narrowly confined") and Magaziner v. Montemuro, 468 F.2d 782, 787 (3d Cir. 1972) ("[t]he judge-inade doctrine of abstention sanctions escape from immediate federal decision only im narrowly limited 'special circuunstances' ").

7. 62 U.S. (21 How.) 582 (1859).

8. 136 U.S. $586(1890)$. 


\section{inal proceedings involving divorce or alimony. ${ }^{9}$}

Three members of the Barber Court dissented, arguing that there could be no diversity jurisdiction because a wife could not have a residence separate from her husband. ${ }^{10}$ The dissent also provided the rationale for the majority's broad disclaimer, declaring that because English Chancery did not have jurisdiction over divorce and alimony, and because federal courts historically derived their equity jurisdiction from Chancery, Congress did not intend to confer jurisdiction over these subjects under the Judiciary Act of 1789.11

In Burrus, ${ }^{12}$ the Supreine Court held that a federal court did not have jurisdiction to grant an award of an infant's custody under the federal habeas corpus statutes. The Court declared that the "whole subject of the donestic relations of husband and wife, parent and child, belongs to the laws of the States and not to the laws of the United States." 13

\section{62 U.S. (21 How.) at 584. The Court stated:}

Our first remark is-and we wish it to be remembered-that this is not a suit asking the court for the allowance of alimony. That has been done by a court of competent jurisdiction. The court in Wisconsin was asked to interfere to prevent that decree from being defeated by fraud.

We disclaim altogether any jurisdiction in the courts of the United States upon the subject of divorce, or for the allowance of alimony, either as an original proceeding in chancery or as an incident to divorce $a$ vinculo, or to one from bed and board.

Id.

10. Id. at 602 .

11. Id. at 605 . The Judiciary Act of 1789 provided that diversity jurisdiction required "a suit of a civil nature at common law or im equity." Act of Sept. 24, 1789, ch. 20, § 11, 1 Stat. 73, 78. This grant of equity jurisdiction has been interpreted to include only that jurisdiction held by the High Court of Chancery in England at the time that the United States became a nation. In late eighteenth century England, Parhament held the power to grant a divorce $a$ vinculo matrimonii (from the bonds of marriage). The ecclesiastical courts had jurisdiction to grant a divorce a mensa et thoro (from bed and board). Maynard v. Hill, 125 U.S. 190, 206 (1888).

The federal diversity statute was anended in 1938 to provide that diversity jurisdiction extends to "all civil actions." Act of June 25, 1948, ch. 85, $\$ 1332,62$ Stat. 930 (codified at 28 U.S.C. $\S 1332$ (1976 \& Supp. V 1981)). Congress did not intend this amendment to change the scope of diversity jurisdiction but rather merely to inake section 1332 "conform to Rule 2 of the Federal Rules of Civil Procedure." Revisor's Notes to 28 U.S.C. § 1332; see, eg., Slapin v. Slapin, 352 F.2d 55, 56 (6th Cir. 1965) (Mathes, J., dissenting) ("The equity jurisdiction of the District Courts, and of their predecessor circuit courts, as it has existed simce conferred by $\$ 11$ of the Judiciary Act of 1789 . . . , has never been held to exceed in scope that which the High Court of Chancery in England possessed at that time."); see also Atlas Life Ins. Co. v. W.I. Southern, Inc., 306 U.S. 563, 568 (1939); Payne v. Hook, 74 U.S. (7 Wall.) 425, 430 (1869); Fontain v. Ravenel, 58 U.S. (17 How.) 369,384 (1855).

12. In re Burrus, 136 U.S. 586 (1890).

13. Id. at 593-94. The quoted dictum refers only to the "laws of the United States but . . . has been taken as referring to judicial competence as well as legislative." HART \& WeCHSLER, supra note 4, at 1017. But see Solomon v. Solomon, 516 F.2d 1018, 1030 (3d Cir. 1975) (Gibbons, J., dissenting). 
The only Supreme Court decision that directly held that federal courts lack jurisdiction over suits for alimony and divorce is Ohio ex rel. Popovici v. Agler. ${ }^{14}$ The Court in Popovici held that federal courts did not have jurisdiction to hear a suit agamst the Vice Consul of Romania, despite the constitutional ${ }^{15}$ and statutory ${ }^{16}$ provisions granting the federal courts exclusive origmal jurisdiction over actions involving foreign consuls, ${ }^{17}$ because it "has been unquestioned for three quarters of a century that the courts of the United States have no jurisdiction over divorce." 18 The Court held that federal court jurisdiction did not exist because the subject matter of the suit was not witlin the competence of the Chancery Courts in England at the time of the adoption of the Judiciary Act of 1789.19

The historical arguments ${ }^{20}$ that the Chancery courts did not have jurisdiction in divorce actions and that a wife cannot have a domicile separate from her husband have been severely criticized ${ }^{21}$ and are no longer viewed as justifications for the exception. The Chancery argument was abandoned because both colonial courts and the Enghish Chancery had some power to determine marital status and had entertamed divorce actions. ${ }^{22}$ This argument never adequately explained the exclusion of child custody cases because these cases were traditionally part of Chancery jurisdiction. ${ }^{23}$ One court even criticized the presumption that the federal courts' jurisdiction should be limited by the jurisdiction of England's ecclesiastical courts, noting that some actions

14. 280 U.S. 379 (1930).

15. U.S. Const. art. III, $\S 2$ provides that "[t]he judicial Power shall extend . . . to all Cases affecting Ambassadors, other public Ministers and Consuls."

16. 28 U.S.C. $§ 1351$ (1976) provides that the "district courts shall have original jurisdiction, exclusive of the courts of the States, of all actions and proceedings against consuls or vice consuls of foreign states."

17. The Vice-Consul sought a writ of prohibition in the federal court to restrain the divorce and alimony proceeding in the state court on the ground that the federal courts had exclusive jurisdiction of the action.

18. Popovici, 280 U.S. at 383.

19. Id at 384.

20. It has never been argued that federal jurisdiction in domestic relations actions is constitutionally limited. Such jurisdiction is apparently constitutionally permissible, because the Supreme Court has heard appeals from territorial courts involving divorce, see, e.g., De La Raina v. De La Rama, 201 U.S. 303 (1906); Simms v. Simms, 175 U.S. 162 (1899), and has recognized the jurisdiction of the lower federal courts in the District of Columbia to exercise exclusive original jurisdiction in divorce actions, see Glidden v. Zdanok, 370 U.S. 530, 581 n.54 (1962).

21. See Lloyd v. Loeffler, 694 F.2d 489, 491-92 (7th Cir. 1982) (noting the "unconvimcing" nature of the historical account, and the "dubious . . . historical pedigree"); Spindel v. Spindel, 283 F. Supp. 797, 802-03, 806-09 (E.D.N.Y. 1968).

22. See Spindel v. Spindel, 283 F. Supp. 797, $806-09$ (E.D.N.Y. 1968).

23. See H. Clark, The law of Domestic Relations in the United States 572 (1968). 
that exist today did not exist in the eighteenth century. ${ }^{24}$ The argument that diversity cannot exist between spouses is now obsolete because today a wife can have a domicile separate from her husband. ${ }^{25}$

Therefore, there is no statutory limitation on federal jurisdiction in domestic relations cases; instead courts have developed a new rationale for the exception based on policy considerations founded on the notions of federahisin and comity. ${ }^{26}$ The inost frequently cited policy reasons for the persistence of the doinestic relations exception are federal court deference to state expertise and competence; ${ }^{27}$ the problem of congested federal courts; ${ }^{28}$ the lack of congressional or Supreme Court approval of jurisdiction in the field of domestic relations:;2 the problem of continuing supervision and nnomitoring of a nodifiable divorce, ali1nony or child custody decree; ${ }^{30}$ the possibility of imcompatible state and federal decrees; ${ }^{31}$ and the threat that litigants will play one court systein against the other. ${ }^{32}$

As courts began to expliasize policy considerations in determining whether to assert jurisdiction in domestic relations actions, they altered the scope of the domestic relations exception and inade largely discretionary decisions whether litigants would be entitled to the statutory right to diversity jurisdiction. In early cases courts held that "the term 'domestic relations' is to be given a broad and liberal construction" 33 and refused to exercise jurisdiction in a case that imvolved any element of domestic relations law. More inodern courts have held that the exception should be "narrowly confined." 34 One court no longer views

24. Lloyd v. Loeffler, 694 F.2d 489, 492 (7th Cir. 1982).

25. See, e.g., Druen v. Druen, 247 F. Supp. 754, 755 (D. Colo. 1965); Garberson v. Garberson, 82 F. Supp. 706, 708 (N.D. Iowa 1949).

26. Huynh Thi Anh v. Levi, 586 F.2d 625, 632 (6th Cir. 1978).

27. See Firestone v. Cleveland Trust Co., 654 F.2d 1212, 1215 (6th Cir. 1981); Bossom v. Bossom, 551 F.2d 474, 475 (2d Cir. 1976); Magaziner v. Montemuro, 468 F.2d 782, 787 (3d Cir. 1972).

28. See Cole v. Cole, 633 F.2d 1083, 1088 (4th Cir. 1980); Crouch v. Crouch, 566 F.2d 486, 487 (5th Cir. 1978).

29. See Sutter v. Pitts, 639 F.2d 842, 843 (1st Cir. 1981); Solomon v. Solomon, 516 F.2d 1018, 1026 (3d Cir. 1975); Phillips, Nizer, Benjamin, Krim \& Ballon v. Rosenstiel, 490 F.2d 509, 514 (2d Cir. 1973).

30. See Huynh Thi Anh v. Levi, 586 F.2d 625, 632 (6th Cir. 1978); Crouch v. Crouch, 566 F.2d 486, 487 (5th Cir. 1978).

31. See Sutter v. Pitts, 639 F.2d 842, 844 (1st Cir. 1981); Crouch v. Crouch, 566 F.2d at 487.

32. See Solomon v. Solomon, 516 F.2d 1018, 1025 (3d Cir. 1975); Zimmerman v. Zimmerman, 395 F. Supp. 719, 721 (E.D. Pa. 1975).

33. Linscott v. Linscott, 98 F. Supp. 802, 805 (S.D. Iowa 1951); see also 1 W. BARRON \& A. HoLTzOFF, supra note 6 , at 214.

34. See Sutter v. Pitts, 639 F.2d 842, 843 (1st Cir. 1981); Cole v. Cole, 633 F.2d 1083, 1088 (4th Cir. 1980); Phillips, Nizer, Benjamin, Krim \& Ballon v. Rosenstiel, 490 F.2d 509, 514 (2d Cir. 1973). 
the domestie relations doctrine as an exception to statutory jurisdiction, but rather, as a part of the federal doctrine of abstention, which should be applied in "narrowly limited" circumstances.35

A confused and mconsistent domestic relations exception doctrine has emerged because the propriety of federal jurisdiction in each case must be determined by weighing several policy considerations, which courts neither weigh equally nor apply consistently. Contemporary courts acknowledge that the "boundaries of the exception are uncertam," 36 and "the results and reasoning of the cases in this area cannot be fully harmonized."37

\section{B. Conflicting Case Law Applying the Domestic Relations Exception.}

There have always been "exceptions" to the domestic relations exception to diversity jurisdiction. The Barber Court provided the first exception, holding that although a federal court did not have jurisdiction to grant a divorce or ahinony, it could determine the validity of a divorce decree. ${ }^{38}$ The Supreme Court in Simms v. Simms ${ }^{39}$ and De La Rama v. De La Rama ${ }^{40}$ also created an exception for appeals from territorial supreme courts. ${ }^{41}$ In addition, the Court permitted divorce jurisdiction im the federal district courts in the District of Columbia. ${ }^{42}$

Since these early Supreme Court cases, lower fcderal courts have added other judge-made "exceptions" to the domestic relations exception. For example, federal courts will entertam tort actions with a domcstic relations component, ${ }^{43}$ but will decline to exercise jurisdiction if the tort action arises from an "ongoing series of disputes ccntering around" the marital relationship. 44 Thus, a fcderal court will hear an action for false imprisonment, unlawful detention and intentional infliction of mental suffering arising from the parental abduction of a child, ${ }^{45}$ but will decline to exercise jurisdiction when a wife sues her exhusband for false imprisoninent of their two infant daughters. ${ }^{46}$

\footnotetext{
35. See Magaziner v. Montemuro, 468 F.2d 782, 787 (3d Cir. 1972).

36. Lloyd v. Loeffer, 694 F.2d 489, 492 (7th Cir. 1982). 1983).

37. Ruffalo v. Civiletti, 539 F. Supp. 949, 955 (W.D. Mo. 1982), affd, 702 F.2d 710 (8th Cir.

38. See Barber, 62 U.S. (21 How.) 582, 592 (1859).

39. 175 U.S. $162,172(1899)$.

40. 201 U.S. 303,308 (1906).

41. See supra note 20.

42. See Glidden v. Zdanok, 370 U.S. 530, 581 n.54 (1962).

43. See Fenslage v. Dawkins, 629 F.2d 1107 (5th Cir. 1980); Daily v. Parker, 152 F.2d 174

(7th Cir. 1945); Cohen v. Randall, 137 F.2d 441 (2d Cir.), cert. denied, 320 U.S. 796 (1943).

44. Bacon v. Bacon, 365 F. Supp. 1019 (D. Or. 1973).

45. See Kajtazi v. Kajtazi, 488 F. Supp. 15 (E.D.N.Y. 1978).

46. See Kilduff v. Kilduff, 473 F. Supp. 873 (S.D.N.Y. 1979).
} 
Contract actions containing domestic relations elements will be entertamed by the federal courts, ${ }^{47}$ but it remains unclear which actions can be characterized as contractual. For example, although a federal court will review a pre-divorce separation agreement 48 and a "contract" incorporated in a divorce decree, ${ }^{49}$ the court will decline to exercise jurisdiction in an action attacking the validity of a property settlement incorporated in a divorce decree. ${ }^{50}$

Federal courts also entertain domestic relations actions in cases involving the constitutionality of a state's action, ${ }^{51}$ a non-frivolous constitutional claim, ${ }^{52}$ a federal question, ${ }^{53}$ and state court decrees ob-

47. See, e.g., Carr v. Wisecup, 263 F.2d 157 (3d Cir. 1959) (contracts executed prior to and in anticipation of separation and divorce).

48. See, e.g., Graning v. Graning, 411 F. Supp. 1028 (S.D.N.Y. 1976).

49. Zimmerman v. Zimmerman, 395 F. Supp. 719, 721 (E.D. Pa. 1975).

50. See Thrower v. Cox, 425 F. Supp. 570, 573 (D.S.C. 1976).

51. The issue most frequently raised is the extent to which one state must enforce the divorce decrees of another state under the full faith and credit clause. U.S. ConST. art. IV, \& 1. The Court in Willians v. North Carolina, 325 U.S. 226 (1945), specifically disclaimed any intent to use this clause as a means of circumventing the domestic relations exception doctrine. Justice Frankfurter, writing for the Court, stated:

The problem is to reconcile the reciprocal respect to be accorded by the ineinbers of the Union to their adjudications with due regard for another most important aspect of our federalisin whereby 'the domestic relations of husband and wife . . . were matters reserved to the States.' . . . The rights that belong to all the States and the obligations which inembership in the Union imposes upon all, are made effective because this Court is open to consider claims . . . that the courts of one State have not given the full faith and credit to the judginent of a sister state .... But the discharge of this duty does not make of this Court a court of probate and divorce.

Id. at 232-33; see also Andrews v. Andrews, 188 U.S. 14, 28 (1903) (suit to determme validity of divorce obtained in another state); Maynard v. Hill, 125 U.S. 190 (1888) (suit to determine validity of legislative divorce); Keating v. Keating, 542 F.2d 910 (4th Cir. 1976) (action to determme validity of divorce decree under full faith and credit clause); Rosenstiel v. Rosenstiel, 278 F. Supp. 794, 799 (S.D.N.Y. 1967) (action seeking declaration of marital status under the full faith and credit clause).

52. A federal court will not exercise jurisdiction if it determines that the constitutional issue is in fact a domestic relations issue in disguise. See Nouse v. Nouse, 450 F. Supp. 97, 102 (D. Md. 1978) (no jurisdiction under civil rights statutes in action alleging interference with communications with children); Delavigne v. Delavigne, 402 F. Supp. 363, 366 (D. Md. 1975), affd, 530 F.2d 598 (4th Cir. 1976) (petition for removal on grounds that the defendant could not enforce his civil rights in state court because the state discriminated in favor of females in donnestic actions denied); see also Bennett v. Bennett, 682 F.2d 1039, 1043 n.5 (D.C. Cir. 1982) ("We note-only for the purpose of illustrating the degree of caution with which we should approach this issue-that a number of federal courts have declined to involve themselves in disputes over child custody even when federal constitutional questions were at stake") (citing Bergstrom v. Bergstroin, 623 F.2d 517 (8th Cir. 1980)); Huynh Thi Anh v. Levi, 586 F.2d 625 (6th Cir. 1978).

53. See Rocker v. Cellebrezze, 358 F.2d 119, 123 (2d Cir. 1966) (jurisdiction to determine whether clainnant was entitled to social security benefits as "wife" of insured); Estate of Borax v. Counmissioner, 349 F.2d 666, 672 (2d Cir. 1965), cert. denied, 383 U.S. 935 (1966) (jurisdiction to determine vahidity of divorce decree for tax purposes); Ruffalo v. Civiletti, 539 F. Supp. 949, 95556 (W.D. Mo. 1982) (jurisdiction to award damages, but not to grant injunctive retief in action arising out of inclusion of plaintiffs son in federal witness program); Stone v. Stone, $450 \mathrm{~F}$. Supp. 
tained by fraud. ${ }^{54}$ Finally, federal courts assert jurisdiction to determine rightful claimants to an estate when marital status is an essential issue $\mathrm{m}$ the case. ${ }^{55}$ The confusion surrounding the domestic relations exception is exemphified by comparing Daily v. Parker, ${ }^{56}$ in which the court held that diversity jurisdiction extended to an action by children against a woman for causing their father to leave them, with Rosenstiel v. Rosenstiel, ${ }^{57} \mathrm{~m}$ which the court held that a federal court did not have jurisdiction over these actions unless a non-frivolous constitutional claim is also presented. ${ }^{58}$

Although courts are attempting to narrow the domestic relations exception by looking beneath the pleadings and applymg policy considerations before declining to exercise jurisdiction, the new rationale based on federalism and judicial economy produces conflicting results. The right of a litigant to diversity jurisdiction often is deterinmed, ultimately, by the location of the district court. By applying the more certain standards for abstention provided by the Supreme Court, inconsistency of results would be lessened, and the statutory right to diversity jurisdiction would be more securely protected.

\section{The Distinction Between Exception and Abstention}

Viewing the domestic relations exception as a jurisdictional necessity mandated by statute differs crucially from viewing it as a discretionary doctrine warranted by principles of comity and federalism. ${ }^{59}$

919, 921 (N.D. Cal. 1978), affd, 632 F.2d 740 (9th Cir. 1980), cert. denied, 453 U.S. 922 (1981) (jurisdiction under ERISA for action against pension plan of employee's spouse for benefits awarded by state court in divorce action).

54. Vann v. Vann, 294 F. Supp. 193, 194 (D. Tenn. 1968). But see Manary v. Manary, 151 F. Supp. 446, 448 (D. Cal. 1957). The Manary court stated:

While a federal court im a diversity case inay, under certain circumstances, enjoin the enforcement of a state court judgment obtained by fraud, it has no power to annul, set aside, or vacate a state court judginent, even if obtained by fraud, where the said court has jurisdiction of the parties and the subject inatter of the action, and the state provides Id.

a remedy for the aggrieved party.

55. Oxley v. Sweetland, 94 F.2d 33, 35 (4th Cir. 1938); Lee v. Hunt, 431 F. Supp. 371 (W.D. La. 1977).

56. 152 F.2d 174, 175 (7th Cir. 1945).

57. 278 F. Supp. 794, 799 (S.D.N.Y. 1967).

58. Id.

59. In Lehman v. Lycoming County Children's Servs. Agency, 102 S. Ct. 3231,3242 (1982), the dissenting Justice characterized this distinction as that between a "jurisdictional" and a "prudential" bar to jurisdiction.

In Lehman, the Supreme Court held that federal habeas corpus jurisdiction does not extend to collateral challenges to state court judgments imvoluntarily terminating parental rights. The Court held that the scope of 28 U.S.C. $\$ 2254$ did not extend to child custody cases because the children were not in the "custody" of the state, id. at 3237, and because the interests of finality and federalisin outweighed any federal interest im individual liberty, $i d$. at 3239. Justice Blackmun 
The policy factors that most federal courts are using to determine whether to decline jurisdiction suggest that the domestic relations exception doctrine is now analogous to the various federal abstention doctrines. ${ }^{60}$ The Supreme Court has never equated the two doctrines;

dissented, saying: "Not one of these reasons is sufficient to erect a jurisdictional, as opposed to a prudential, bar to federal habeas relief." Id. at 3242 (Blackmun, J., dissenting). Responding to the inajority's federalism and finality concerns, Justice Blackmun stated: "While 1 am fully sensitive to these concerns, once agam I cannot understand how they deprive federal courts of statutory jurisdiction to entertain habeas petitions." $I d$. at 3243. He concluded that there was no strict jurisdictional bar and that a "discretionary limit would have allowed the writ to issue only in those very rare cases that demanded its unique "capacity to . . . cut through barriers of form and procedural inazes." "Id. at 3245.

The court's argument in denying jurisdiction in Lehman raises the same questions as the debate regarding whether there is a strict jurisdictional bar in the domestic relations area, or whether there may be a jurisdictional bar based on deference to state expertise. Justice Blackmun's dissent im Lehman supports the conclusion that there is not a jurisdictional bar, and therefore, the domestic relations exception should be determined by a discretionary limit. The history of the writ of habeas corpus as an extraordinary remedy led the majority in Lehman to conclude that the writ should issue only when the "federal imterest in individual hiberty is so strong that it outweighs federahism and finahty concerns." Id. at 3240.

The question in determining the scope of the domestic relations exception is whether federal courts should abstain from exercising their original jurisdiction in deference to state expertise. Federal habeas jurisdiction in child custody cases poses a mucl greater threat to state judicial processes than the ordinary domestic relations case because a federal court can overturn a final state court judgenent on habeas corpus review. Id. at 3239.

The state's interest in finality, rehed on by the Lehman Court, is also not an issue in the determination of the scope of the domestic relations exception. A decision by a federal court in a domestic relations action is as determinative of the issue as a decision by a state court. Therefore, adjudication by federal courts in domestic relations cases is less disruptive than in child custody cases.

In addition, even if federal habeas jurisdiction is demed in child custody cases, the petitioner has other federal remedies available. The Court in Lehman demed only collateral review through federal habeas jurisdiction. The petitioner in Lehman could have instituted an action for direct review under § 1983 of the Civil Rights Act, 42 U.S.C. \& 1983 (1976 \& Supp. V 1981), or petitioned for direct appeal or certiorari. See Note, Federal Habeas Corpus in Child Custody Cases, 67 VA. L. REV. 1423, 1440-45 \& nn.123-24 (1981). In the domestic relations cases, however, if the court refuses to exercise diversity jurisdiction, the parties will not have a federal remedy unless a federal question is also raised.

60. No lower court has explicitly stated that the domestic relations exception is no longer a question of statutory jurisdiction and is instead a part of the abstention doctrine. Some courts analyze the issue as an exception to diversity jurisdiction and alternatively as part of the doctrime of abstention. See Magaziner v. Montemuro, 468 F.2d 782, 787 (3d Cir. 1972); Spimdel v. Spindel, 283 F. Supp. 797, 811-12 (E.D.N.Y. 1968). Other courts explicitly state that they are not deciding whether the issue technically falls within the exception but rather are declining jurisdiction under the abstention doctrine. See, e.g., Armstrong v. Armstrong, 508 F.2d 348, 350 (1st Cir. 1974).

According to the doctrime of abstention, the federal court concedes jurisdiction but declimes to exercise it in the interest of comity and federalism unless the interests of the litigant outweigh the federahisin concerns. For example, in Wasserman v. Wasserman, 671 F.2d 832 (4th Cir.), cert. denied, $103 \mathrm{~S}$. Ct. 372 (1982), the federal district court was the only available forum because the state statute of limitations had run. The appellees contended that this was irrelevant because the district court never had jurisdiction because the action fell within the domestic relations exception. Brief for Appellee at 14, Wasserman v. Wasserman, 671 F.2d 832 (4th Cir. 1982). The appellants 
but it is unclear what doctrine other than abstention can support a federal court's decision in a domestic relations case to decline to hear a case when jurisdiction has otherwise been properly invoked. The argument that Congress intended to limit federal jurisdiction to that exercised by the English Chancery courts has been repudiated. ${ }^{61}$ There is apparently no constitutional mandate for the domestic relations exception, because the Supreme Court has lieard appeals in divorce actions froin territorial courts. ${ }^{62}$ Courts invoking the domestic relations exception are employing the policy factors that underlie the federal doctrine of abstention, but are failing to rely on the abstention cases as precedent. Therefore, to avoid inconsistent results, federal courts should adhere to the federal abstention doctrine standards when they determine whether to decline to exercise jurisdiction in domestic relations actions.

Several of the policy factors ${ }^{63}$ that federal courts have used to determine whetlier to decline jurisdiction im a domestic relations action should be eliminated from the analysis because they are inappropriate under the existing abstention doctrines. For example, it is questionable whether federal court congestion will itself justify abstention. ${ }^{64}$ The American Law Institute, in its proposal to codify the abstention doctrine, excluded this argument from its definition of the conditions justifying abstention.65 There is no explicit Supreme Court decision concerning this issue, ${ }^{66}$ and Professor Wright notes that decisions relying on this justification "seem to go beyond anything required by the demands of federalism that are at the heart of the abstention doctrine."67 Similarly, the risk that parties will attempt to play one court system against the other is inherent in diversity jurisdiction and should not be a factor in the abstention analysis. The argument that courts

responded that the federal court did have jurisdiction by virtue of diversity of citizenship but could decline to exercise that jurisdiction by reason of abstention. Appellants argued that because the abstention doctrine is based on the premise that the federal courts will decline jurisdiction so that a state court can decide the case, the district court should not have declined jurisdiction because there was no longer an available state forum. Brief for Appellant at 5, Wasserman v. Wasserman, 671 F.2d 832 (4th Cir. 1982).

61. See supra notes 20-25 and accompanying text.

62. See supra note 20.

63. See supra text accompanying notes 26-32.

64. See generally Ashman, Alfini, \& Shapiro, Federal Abstention: New Perspectives on Its Current Vitality, 46 Miss. L.J. 629 (1975).

65. See American Law Institute Study of the Division of JuRisdiction Between State AND Federal Courts 49 (1969) [hereinafter cited as ALI STUdy].

66. Compare Wisconsin v. Constantimeau, 400 U.S. 433, 443 (1971) (Burger, C.J., dissenting) (congestion of federal courts is an appropriate justification for abstention), with Thermtron Prods., Inc. v. Hermansdorfer, 423 U.S. 336, 344 (1976) (a suit may not "be dismissed or referred to state courts" because a federal court "considers itself too busy to try it").

67. See C. WRight, The Law of Federal Courts 228 (3d ed. 1976). 
must wait for Congress to confer jurisdiction is also flawed; Congress has already done so in 28 U.S.C. $\S 1332.68$ The question is not whether jurisdiction exists, but instead, whether it should be exercised. Finally, the Supreme Court has specifically rejected the possibility of incompatible state and federal decrees as a justification for abstention. ${ }^{69}$

The remaining domestic relations doctrine policy considerations of federal court deference to state expertise and competence and the problem of contimumg supervision and monitoring of a modifiable divorce, alimony or custody decree, are factors related to the interests of federalism and comity that underlie the abstention doctrine. These interests, however, are not necessarily furthered by abstention in each case that contains a domestic relations component. Although no clear standards emerge from the various abstention doctrines, ${ }^{70}$ a federal court should refuse to assume jurisdiction in a specific domestic relations case only if that refusal furthers those policy interests underlying the abstention doctrines.

\section{The Domestic Relations Exception and the ABSTENTION DOCTRINES}

\section{A. The Abstention Doctrines.}

There are approximately four ${ }^{71}$ distinct abstention doctrines. According to Pullman ${ }^{72}$ abstention, a federal court should abstain from deciding a case involving a sensitive constitutional issue when state court determination of an unsettled question of state law might make it unnecessary to confront the constitutional question. ${ }^{73}$ Under Burford ${ }^{74}$ abstention, federal courts may decline to exercise jurisdiction when federal adjudication would be "disruptive of state efforts to establish a coherent pohicy with respect to a matter of substantial public concern."75 Under Younger 76 abstention, or more properly, the doctrine of "equitable restramt," a federal court will decline to enjoin either a state

68. 28 U.S.C. \& 1332 (1976 \& Supp. V 1981).

69. See Colorado River Water Conservation Dist. v. United States, 424 U.S. 800, 816 (1976) ("the mere potential for conflicts in the results of adjudications, does not, without nore, warrant staying exercise of federal jurisdiction").

70. See L. Tribe, american Constitutional Law 154 (1978).

71. Neither the Supreme Court nor commentators have been able to agree how nuany abstention doctrines exist today. The four categories discussed here are based on the Court's analysis in Colorado River Water Conservation Dist. v. United States, 424 U.S. 800, 813-17 (1976).

72. See Railroad Comm'n v. Pullman Co., 312 U.S. 496 (1941).

73. See id. at 500.

74. See Burford v. Sun Oil Co., 319 U.S. 315, 334 (1943).

75. Colorado River Water Conservation Dist. v. United States, 424 U.S. 800, 814 (1976).

76. See Younger v. Harris, 401 U.S. 37 (1971). 
criminal prosecution begun prior to the institution of the federal suit except where necessary to prevent immediate irreparable injury, ${ }^{77}$ or a state civil proceeding in which important state interests are involved. ${ }^{78}$ Finally, under Colorado River ${ }^{79}$ abstention, a federal court may dismiss an action "due to the presence of a concurrent state proceeding for reasons of wise judicial administration." 80

This note addresses only the Burford and Younger doctrines. Few doinestic relations exception cases present the Pullman abstention paradigm of both unsettled state law and a sensitive constitutional issue. Furthermore, Colorado River abstention does not apply because concurrent jurisdiction over domestic relations actions does not involve the "exceptional circumstances"81 upon which such abstention is based.

\section{B. Diversity Jurisdiction and the Abstention Doctrine.}

The Supreine Court could resolve the uncertainty surrounding federal domestic relations jurisdiction by amouncing that the doinestic

77. See Samuels v. Mackell, 401 U.S. 66, 69 (1971).

78. See Moore v. Sims, 442 U.S. 415, 423 (1979).

79. See Colorado River Water Conservation Dist. v. United States, 424 U.S. 800, 814 (1976).

80. Id. at 818.

81. Id In Colorado River, the Court found that even if traditional abstention requirements are not met, a court may decline to exercise jurisdiction in deference to a concurrent state proceeding " for reasons of wise judicial administration, giving regard to conservation of judicial resources and comprehensive disposition of hitigation." "Id. at 817 (quoting Kerotest Mfg. Co. v. CO-Two Fire Equip. Co., 342 U.S. 180, 183 (1952)). The Colorado River Court was not addressing the possibility of concurrent jurisdiction but was concerned with avoiding duplicative litigation when there was already a concurrent state proceeding. Colorado River Water Conservation Dist. v. United States, 424 U.S. 800, 817 (1976). The Court limited its holding by noting that "the mere potential for conflicts in the results of adjudications, does not, without more, warrant staying exercise of fedcral jurisdiction." Id. at 816. It also held that only "exceptional" circumstances and the "clearest of justifications will warrant dismissal" due to the presence of a concurrent state proceeding. Id. at 818-19. The Court found precedent for sucl abstention in cases holding that the court first assuming jurisdiction over the res in the action liad exclusive jurisdiction over the matter, im cases dismissing actions under the forum non conveniens doctrine, and in cases allowing dismissal of a claim to avoid piecemeal litigation. See id. at 818 . It found such circumstances present in the Colorado River factual situation. The Court noted several factors in the case which together constituted "exceptional circumstances." Id. at 819 . These included: the congressional policy behind the federal statute invoked in the case favoring avoidance of piecemeal litigation of water rights; the absence of any proceedings other than the filing of the complaint in the district court; the great distance between the federal and state courts; the "extensive involvement of state water rights"; and the participation of the federal government in water rights actions in other courts in the state. Id. at 819-20. It is important to note that the Court emphasized the "virtually unflagging obligation of the federal courts to exercise the jurisdiction given them." Id. at 817. This statcment implies that the often articulated policy justification for the domestic relations exception-the possibility of incompatible federal and state court decrees-is not in itself sufficient to justify abstention. Furthermore, under the "exceptional circumstances" test set forth im Colorado River, the inere fact of a concurrent state domestic relations proceeding will not justify abstcntion. 
relations exception is but another abstention doctrine. ${ }^{82}$ But such a pronouncement would conflict with the Court's previous decisions concerning abstention in diversity cases. ${ }^{83}$ The presence of diversity jurisdiction in an action in which the Court chooses to abstain has caused considerable conflict among the Supreme Court Justices. ${ }^{84}$ In diversity cases the Supreme Court has developed special safeguards that would apply equally well to abstention in domestic relations cases. ${ }^{85}$

1. Burford Abstention. The Court has recognized that abstention may be appropriate in diversity cases. ${ }^{86}$ The Court first addressed the issue in Meredith v. City of Winter Haven ${ }^{87}$ In Meredith the Court held

82. The American Law Institute adopted this approach in its Study of the Division of Jurisdiction Between State and Federal Courts. This study proposed that Congress enact a new code section, excluding domestic relations actions from the jurisdiction of federal courts, unless otherwise provided by a separate act of Congress. ALI STUDY OF THE DIvision OF JURISDICTION Between State and Federal Courts 36 (Tent. Draft No. 6, 1968). This proposal was not included in Part I of the Institute's Official Draft. See ALI STUdy OF THE Division OF JURISDICtion Between State and Federal Courts (Oficial Draft, Part I, 1965).

83. See infra notes $86-110$ and accompanying text.

84. See Louisiana Power \& Light Co. v. City of Thibodaux, 360 U.S. 25, 31-44 (1959) (Brennan, J., dissenting); Burford v. Sun Oil Co., 319 U.S. 315, 336-48 (1943)(Frankfurter, J., dissenting).

85. The practice of judicial abstention in cases in which jurisdiction is based solely on diversity is itself something of an anomaly. Nothing in the federal diversity statute allows federal courts any ineasure for discretion. Early Supreme Court cases indicate that if federal jurisdiction existed, a litigant had an absolute right to be heard in a federal forum. See, e.g., Cohens v. Virginia, 19 U.S. (6 Wheat.) 264, 404 (1821) ("We have no [more] right to decline the exercise of jurisdiction which is giveu, than to usurp that which is not given."). Yet the entire notion of abstention contradicts the idea of an absolute right to a federal foruin.

When a hitigant invokes federal jurisdiction in a diversity case, he is usually seeking protection from the possibility of local prejudice. Yet when a federal court abstains the litigant is relegated to a state court; thus abstention causes the very result that the diversity statute was designed to avoid. See HART AND WechSLER, supra note 4, at 1051-58; Marsh, Diversity Jurisdiction: Scapegoat of Overcrowded Federal Courts, 48 BRookLYN L. REV. 197, 201-05 (1982). Fear of local prejudice as a basis for federal jurisdiction has been criticized, but "no one has yet established, by survey or other empirical proof, that parochial bias has so dissipated that diversity jurisdiction has become obsolete." Id. at 203 (footnote omitted). Indeed, the possibility of local prejudice is greater in domestic relations actions because of the peculiar state interest involved. See Williams v. North Carolina, 317 U.S. 287, 297 (1942).

In view of the current debate over the very existence of federal diversity jurisdiction it is important to state at this point that this note does not assert that federal courts ought to grant divorce, child custody, and alimony decrees. It merely concludes that under current law these domestic relations actions can be precluded from federal jurisdiction only by proper application of the recognized abstention doctrines. Until Congress amends the diversity statute, a higant has a statutory right to be heard in a federal forum when the diversity requirenents are met; application of the recognized abstention doctrines to the domestic relations exception is necessary to protect this right from unprincipled limitation.

86. See generally Gowen \& Izlar, Federal Court Abstention in Diversity of Citizenship Litigation, 43 TEX. L. REV. 194 (1964).

87. 320 U.S. 228 (1943). The petitioners in Meredith, municipal bondholders, sued in a federal district court seeking a declaration that the defendant city should not call and retire the bonds 
that difficulty in ascertaining state law does not itself justify abstention in a diversity case. ${ }^{88}$ The Supreme Court has, however, upheld abstention in a diversity action in Burford v. Sun Oil Co. ${ }^{89}$ and several subsequent decisions, even in the absence of unsettled state law.

Jurisdiction in Burford was based on both diversity and the existence of a federal question. ${ }^{90}$ In Burford, the Court upheld abstention in a suit brought to enjom the execution of an order of the Texas Railroad Commission. The Court emphasized the complexity of the issue: the comprehensive regulatory system for conservation of oil and gas im Texas, and the fact that the Texas legislature had provided for direct, de novo review of the Commission's orders in the state courts of only one county in the state.91 The Court concluded that the issue so "clearly involves basic problems of Texas policy that equitable discretion should be exercised to give the Texas courts the first opportunity to consider them."92

Alabama Public Service Commission v. Southern Railway Co. ${ }^{93}$ involved a specialized statutory scheme for judicial review, which presented no issue of unsettled state law. Jurisdiction was predicated on both diversity and existence of a federal question. The Court found Burford abstention appropriate because the controversy involved predominantly local issues ${ }^{94}$ and because the statute assigned all appeals of Commission decisions to a smgle court. ${ }^{55}$ In Colorado River Water Conservation District v. United States, 96 the Supreme Court characterized Burford and Southern Railway as requiring abstention

and an injunction restraining the city from calling the bonds. Jurisdietion rested solely on diversity of citizenship. The district court dismissed the complaint for failure to state a claim. The court of appeals affirmed the dismissal, basing the decision on its finding of unsettled state law.

88. Id. at 234. The Court continued:

The diversity jurisdiction was not conferred for the benefit of the federal courts or to serve their convenieuce.... In the absence of some recognized public policy or defined principle guiding the exercise of the jurisdiction conferred, which would in exceptional circumstances warrant its non-exercise, it has front the first been deemed to be the duty of the federal courts, if their jurisdiction is properly invoked, to decide questions of Id. state law whenever necessary to the rendition of a judgment.

89. 319 U.S. 315 (1943).

90. The federal question presented in Burford was not, however, an additional ground for abstention. Colorado River Water Conservation Dist. v. United States, 424 U.S. 800 , 815 n.21 (1976).

91. 319 U.S. at 325 .

92. Id. at 332 . In a vigorous dissent, Justice Frankfurter empliasized the importance of diversity jurisdiction as "a duty enjomed by Congress and made manifest by the whole listory of the jurisdiction of the United States courts." Id. at 336 (Frankfurter, J., dissenting).

93. 341 U.S. 341 (1951).

94. Id. at 349-50.

95. Id at 348.

96. Colorado River, 424 U.S. 800. 
when federal review "would be disruptive of state efforts to establish a coherent policy with respect to a matter of substantial public concern."97 Thus, Burford abstention is appropriate when the state has a unified procedure for review of administrative orders and when federal intervention would disrupt the state's efforts to establish a coherent policy on a matter of substantial public concern.

In Zablocki v. Redhail, ${ }^{98}$ the Supreme Court implied that the mere existence of a doniestic relations component will not satisfy the "substantial public concern" requirement. In Zablocki the Court found Burford inapplicable in an action challenging the constitutionality of a Wisconsin statute forbidding any person under a court-ordered obligation to support a minor child to inarry without first obtaming an order indicating court approval.99 To get court approval under the statute the applicant had to show that the support obligation had been inet and that the child was not likely to become a public charge. The Zablocki Court found Burford inapplicable because the case did not involve complex issues of state law, and because resolution would not be " disruptive of state efforts to establish a coherent policy with respect to a inatter of substantial public concern." "100

Apparently, the existence of a coniplex administrative scheme in addition to a substantial state interest is a prerequisite to Burford abstention in the absence of an elentent of unsettled state law. This proposition is consistent with the Suprene Court's reasoning in Louisiana Power \& Light Co. v. City of Thibodaux ${ }^{101}$ and County of Allegheny v. Frank Mashuda Co. ${ }^{102}$ which followed Burford, and which require a substantial state interest and an element of unsettled state law before a court can abstain in a diversity action. ${ }^{103}$

The Court upheld abstention in a diversity action in Thibodaux, over a vigorous dissent, ${ }^{104}$ and in apparent contradiction to its decision

97. Id. at 814.

98. 434 U.S. 374 (1978).

99. Id. at $379-80$.

100. Id. at 379 n.5 (quoting Colorado River, 424 U.S. at 814-15); see also Wynn v. Carey, 582 F.2d 1375 (7th Cir. 1978) (Burford abstention inapplicable in action seeking declaratory and injunctive relief against alleged unconstitutional provisions of the Illinois Abortion Parental Consent Act).

101. 360 U.S. 25 (1959).

102. 360 U.S. 185 (1959).

103. This proposition is also supported by the Court's application of Burford abstention in Kaiser Steel Corp. v. W.S. Rancl Co., 391 U.S. 593 (1968) (per curiam). Kaiser did not involve a state regulatory or adninistrative scheme but presented an issue of water rights, of vital concern in the arid state of New Mexico, and according to the Court, "a truly novel one." Id. at 594.

104. Justice Brennan, in his dissent in Thibodaux, argued that there was no more possibility of conflict with the state in an eminent domain proceeding than there would be in an ordinary negligence or contract actiou, 360 U.S. at 35 (Brennan, J., dissenting), that abstention was appropriate 
the same day in Mashuda. Both cases involved the question of the state's eminent domain power. Relying on the "special and peculiar nature" of eminent domain proceedings as "intimately involved witl sovereign prerogative," 105 and on the fact that the issues are determined by local variation in legislation, the Thibodaux Court held that abstention was justified. ${ }^{106}$ But the implication that the Thibodaux Court's decision was based on the peculiar nature of eminent domain proceedings was undercut when Mashuda held that a district court liad improperly abstained in another case mvolving eminent domain proceedings. In Mashuda the Court lield that abstention was inappropriate because the exercise of jurisdiction

would not entail the possibility of a premature and perhaps unnecessary decision of a serious federal constitutional question, would not create the hazard of unsettling some dehicate balance in the area of federal-state relationships, and would not even require the court to guess at the resolution of uncertain and difficult issues of state law. ${ }^{107}$

The Mashuda Court characterized the doctrine of abstention as "an extraordinary and narrow exception" that can be justified "only in the exceptional circumstances where the order . . . would clearly serve an important countervailing interest." 108 The Court explained its holding in Thibodaux by stating that "the fact that a case concerns a State's power of eminent domam no inore justifies abstention than the fact that it involves any other issue related to sovereignty." 109 Implicit

in only a "narrow area" of cases, and that "jurisdiction must be exercised in all other situations" because it "would obviously wreak havoc with federal jurisdiction if the exercise of that jurisdiction was a matter for the ad hoc discretion of the District Court in each particular case." Id. at 36.

105. Thibodaux, 360 U.S. at 28.

106. Id. at 29. The Thibodaux Court distinguished Meredith on the ground that the issue in Meredith was whether "jurisdiction must be surrendered to the state court," whereas Thibodaux involved staying the disposition of a retained case. $I d$. at 27 n.2. This might be an important consideration in the inquiry of whether abstention is appropriate in diversity cases. A litigant's right to a federal forum is not abrogated when a court in a diversity case merely stays disposition pending state court determination of unsettled state law. The right, however, is impermissibly abrogated if a court orders dismissal. This distinction has not been viewcd by the Court as controlling because under the Burford abstention doctrine, which is applied in diversity cases, the court is required to dismiss the action.

107. 360 U.S. at 186-87.

108. Id. at $188-89$.

109. Id. at 191-92. The Court, in determining that the state's interest in eminent domain proceedings was not sufficient to justify abstention, cited other interests that would also not be sufficient:

Surely eminent domain is no more mystically involved with "sovereign prerogative" than a State's power to regulate fishing in its watcrs, Toomer v. Witsell, 334 U.S. 385, its power to regulate intrastate trucking rates, Public Utilities Comm'n of California v. Umited States, 355 U.S. 534, a city's power to issue certaim bonds without a referendum, Meredith v. Winter Havcn, 320 U.S. 228, its power to license motor vehicles, Chicago v. Atchison, T \& S.F.R. Co., 357 U.S. 77, and a lost of other governmental activities. Id. at 192. 
in the reasoning in these two cases is the recognition that the right to diversity jurisdiction outweighs the state's interest in eminent domain proceedings, a state imterest that would seem to be as great as that in domestic relations cases. Lower federal courts have interpreted the distinction between Mashuda and Thibodaux as providing a standard for abstention in diversity cases that lack an unsettled state law issue: both unclear state law and a broad impact on state policy nuust be present in the case. ${ }^{110}$

Therefore, the Burford line of cases stands for the proposition that a federal court inay not abstam in a diversity action unless there is a state interest of substantial concern and either an issue of unsettled state law, or a complex administrative scheme with which federal review would interfere.

2. Application of Burford Abstention Principles to Domestic Relations Actions. Whether based on tradition ${ }^{111}$ or precedent, a state's interest $m$ domestic relations is of substantial concern, and therefore is sufficient to meet the first requirenient for Burford abstention in diversity cases. Under the Burford abstention doctrine, if there is also an issue of unsettled state law in a domestic relations action, then abstention is justified. ${ }^{112}$ The question remaims whether, absent unsettled state law, the state's admimistration of domestic relations will satisfy the "complex administrative schenie" requirentent found in Burford. Although some states do have specializcd courts that adjudicate only domestic relations actions, ${ }^{113}$ fanily and juvenile court systems cannot be equated with the complex administrative schemes found in Burford and Southern Railway; nevertheless, the reasoning in these two cases is probably applicable to the analogous comprehensive state admimistrative and judicial mechanisms eniployed in domestic relations actions. Burford abstention, however, must be limited to those cases in which a federal court is asked to grant a divorce, child custody, or alimony de-

110. See, e.g., Smith v. Metropolitan Property \& Liab. Ins. Co., 629 F.2d 757, 760 (2d Cir. 1980); Miller Davis Co. v. Illinois State Toll Higlıway Auth., 567 F.2d 323 (7th Cir. 1977). The court in Miller Davis stated:

It seems that before a federal court abstains in a diversity case, and forces a plaintiff to sacrifice completely his right to a federal forum, it should be convinced that the state issues which are unclear are considerably complex and that their incorrect resolution will threaten an inportant state policy.

Id. at 326.

111. The tradition arose from the idea that states had to assert broad power over marital status as part of their duty under the police power to protect the public welfare. See H. CLARK, supra note 23 , at 35 .

112. This analysis was apphed in Phillips, Nizer, Benjamin, Krin \& Ballon v. Rosenstiel, 490 F.2d 509, 515-16 (2d Cir. I973).

113. See, e.g., Cal. Clv. Proc. Code $\S 1740$ (West Supp. 198I); N.Y. Fam. CT. Act $\$ \S 411$, 511,652 (McKinney 1975 \& Supp. 1982). 
cree; inodify, and thus continuously supervise, a divorce, child custody, or alimony decree; or grant rehef that would in effect determine present or future rights under one of these decrees. Only in these cases is something reseinbling a complex state administrative scheme involved.

Abstention is appropriate only when the action requires detcrmination of peculiarly local factors and the assistance of local agencies. For example, in a custody determination courts generally consider such local factors as the standard of living and the financial needs and resources of each party. ${ }^{114}$ This is also true in alimony determinations and actions to inodify a decree, which usually involve the question of the feasibility of employment. ${ }^{115}$ Further, in custody detcrmimations a court will often require a report from a local social services counselor, ${ }^{116}$ and many courts in divorce actions require legally supervised counseling. ${ }^{117}$ Burford abstention is appropriate in these actions both because a federal court determination of these issues would enmesh the federal court in the operation of the local agencies and thereby disrupt the local administrative scheme, and because the federal system lacks facilities for counseling and other social services. Abstention may be inappropriate, however, in cases where state courts have issued a final decree, because local factors and agencies will no longer be involved.

Analysis of three recent federal appellate decisions demonstrates how Burford abstention could be applied in domestic relations actions. The cases considered whether the tort of parental kidnapping, or "childnapping," falls within the domcstic rclations exception. All three cases held that it does not, but two of the courts held that the domestic rclations exception precludcd certain types of relief. This conclusion is consistcnt with the apphication of Burford abstention to the domestic relations exception.

In Wasserman $v$. Wasserman, ${ }^{118}$ the plaintiff brought a diversity action alleging child enticement and intentional infliction of emotional distress. The district court dismissed for lack of subject matter jurisdiction. The United States Court of Appeals for the Fourth Circuit reversed the decision of the district court and remanded the case. The Court of Appeals for the Fourth Circuit found that the torts did not fall within the domestic relations exception because they were not depen-

114. See Freed \& Foster, Family Law in the Fifty States, 8 FAM. L. REP. (BNA) 4065, 4087 (1982).

115. See id at 4084 .

116. See id at 4066 .

117. See, e.g., Tex. Fam. Code ANN. $\$ 3.54$ (Vernon 1975).

118. 671 F.2d 832 (4th Cir.), cert. denied, 103 S. Ct. 372 (1982). 
dent on a family relationship, ${ }^{119}$ sought no adjustment of family status, and did not require application of any rule "particularly marital in nature." 120

The issue of injunctive relief to remedy childnapping was addressed by the Court of Appeals for the District of Columbia Circuit in Bennett v. Bennett..$^{121}$ In Bennett, the plamtiff brought an action agamst his former wife seeking monetary rehef and an injunction prohibiting her from interfering with his child custody rights. ${ }^{122}$ The court held that the district court had jurisdiction to entertain the suit and to award damages, but could not grant injunctive relief because it would require an inquiry into the present interests ${ }^{123}$ of the minor children, an mquiry that is "within the peculiar province, experience, and competence of the state courts." 124 This analysis is consistent with the policy in Burford that federal courts should avoid adjudication of issues when the state has developed a particular administrative scheine for determmation of those issues.

The Bennett court, however, was faced with another issue counseling agamst abstention, the madequacy of the state forum. Only a federal court could provide rehef if the Ohio state court refused to enforce the District of Columbia custody decree. The court responded that federal jurisdiction was not the best solution to this dilemina, preferring instead the solutions presented by the Umiform Child Custody Jurisdiction Act, ${ }^{125}$ or the Parental Kidnapping Prevention Act of 1980. ${ }^{126}$ The court noted that "conspicuously absent from this comprehensive enactment is any provision creating or recognizing a direct role for the fed-

119. Wasserman, 671 F.2d at 834-35.

120. Id. at 835 .

121. 682 F.2d 1039 (D.C. Cir. 1982).

122. Id. at 1039 .

123. The "present interests" of the child are those factors which a court must weigh in deciding the custody of the child. See H. CLARK, supra note $23, \S \S 17.4-17.6$ (1968).

124. Bennett, 682 F.2d at 1043. Judge Edwards concurred in the holding that federal diversity jurisdiction extended to granting damages for the tort of "childnapping," id. at 1044 (Edwards, J. concurring in part and dissenting in part), but dissented froin the part of the opinion excluding injunctive relief from federal jurisdiction, because "[e]nforcement of a valid and final state decree does not require a federal court to imquire into the present best interests of minor children; rather, the federal court need only give effect to the binding decision of a state court." Id. at 1045 .

125. UNIForm Child Custody JuRISDiction ACT $\S \S 1-28,9$ U.L.A. 116 (1979).

126. Pub. L. No. $96-611, \S \S 6-10,94$ Stat. 3568 (1980) (codified at 28 U.S.C. $\S 1738 \mathrm{~A}, 42$ U.S.C. $\S 663,18$ U.S.C. $\S 1073$ (Supp. V 1981)) [hereinafter cited as PKPA].

The PKPA was enacted in part in response to the reluctance of the Supreme Court to extend application of the full faith and credit clause, U.S. CoNST. art. IV, $\S 1$, to child custody decrees. See Comment, Parental Kidnapping: Can the Uniform Child Custody Jurisdiction Act and Parental Kidnapping Prevention Act of 1980 Effectively Deter It?, 20 DuQ. L. Rev. 43, 47-49 (1981). In response to this problem the PKPA requires that every state recognize and enforce without inodification the child custody decrees of sister states. 28 U.S.C. $\S 1738$ A(a) (Supp. V 1981). 
eral courts in determining child custody. Indeed the legislative history of the Act nakes clear that Congress deliberately and einphatically omitted such a role."127 Therefore, the court in Bennett did not err in abstaining because the litigants could obtain adequate relief in other courts. 128

The United States Court of Appeals for the Seventh Circuit used a similar analysis in Lloyd $v$. Loeffler ${ }^{129}$ with regard to the question of an escalating punitive dainage award in a child kidnapping case. The trial court judginent in Lloyd provided that the punitive dainage award would increase two thousand dollars for each nonth that the child was not returned to his father's custody.

The appellate court in Lloyd found that the tort was not within the donestic relations exception because the suit did not contest the validity of the custody decree, the suit did not "seek one of the distinctive reinedies provided by family courts," 130 the issues were not those that only state courts are coinpetent to resolve, ${ }^{131}$ and the issues required "no special experience with the business of domestic relations."132 The court believed, however, that the variable award of punitive dainages was "the practical equivalent of an injunction" ordering the abductors to return the child to her father, and thus was an miplicit decision of who should have custody of the child. ${ }^{133} \mathrm{Had}$ the issue been raised, there would have been a "substantial question" whether the award was within the court's subject inatter jurisdiction. ${ }^{134}$ Again, the reasoning is consistent with the reasoning in the Burford line of cases because the custody decision involves peculiarly local concerns. ${ }^{135}$

127. Bennett, 682 F.2d at 1043.

128. If no state forum or other relief is available, the court should not abstain. See Ruffalo v. Civiletti, 702 F.2d 710, 718 (8th Cir. 1983) (holding the domestic relations exception inapplicable because state court could not grant "effective" relief to the plaintiff).

129. 694 F.2d 489 (7th Cir. 1982).

130. Id. at 492.

131. Id at 493 .

132. Id.

133. Id. at 494.

134. Id. The Lloyd court could only note its disagreement because the only people who could complain were fugitives and not before the court. The court discussed the issue to avoid creating the false impression that the issuance of such a decree raises no jurisdictional problems. Id. at 493-94.

135. The Lloyd court also presented the concept of "ancillarity" as an alternative rationale for much of the domestic relations exception. The court reasoned:

When a case must begin in state court, as a divorce or custody case must, retention of any ancillary litigation in the same court is supported by considerations of judicial economy . . . [and] relative expertness since the issues in an ancillary proceeding may be the same as those in cases that are within the core of the doinestic relations exception. . . . [It also] avoids "piecemeal, duphicative, or mexpert handling of what is substantially a single controversy.

Id. at $492-93$. 


\section{Younger and the Domestic Relations Exception.}

In a development that is closely analogous to the domestic relations exception to federal diversity jurisdiction, several federal courts have held that the Younger doctrine of equitable restraint requires deferral to pending or ongoing state doinestic relations proceedings. ${ }^{136}$ This practice, which has an impact upon hitigation of doinestic relations actions in federal courts parallel to that of the domestic relations "exception," suffers from inany of the same infirmities.

The Younger doctrine of equitable restraint is not directly applicable to the domestic relations exception to diversity jurisdiction. Younger apphies only when jurisdiction is based upon a federal question, and then only when a federal court is asked to enjoin a pending state proceeding. Neither of these Younger requirements is present in a "domestic relations exception" case, and therefore the policies embodied in Younger cannot lend support to the doinestic relations exception. Younger, as applied to domestic relations actions, is analogous to the domestic relations exception, however, because both are premised on the strong state interest in dornestic relations law. ${ }^{137}$ Therefore the same problem arises in the equitable restraint cases as in the exception cases: when does federal court review of an action with a domestic relations component interfere with the state's pecuhar interest in domestic relations law?

The bare holding in Younger was that absent extraordinary circumstances, a federal court may not enjoin a pending criminal trial in a state court. Younger was premised on the interests of equity, coinity, and federalism, policies that are directly applicable to the state's interest in domestic relations actions. The Court's subsequent application of the Younger doctrine to certain types of civil actions could have serious imphications for domestic relations actions, because such actions frequently involve ongoing state proceedings due to the modifiable nature of divorce, alimony, and child custody decrees. But neither the policies of equity, comity, and federahism, nor these subsequent decisions concerning Younger equitable restraint warrant the conclusion that federal courts inust abstain in every domestic relations action in

This alternative rationale inust also be rejected. The risk of inconsistent federal and state decrees, and avoidance of piecemeal, duplicative litigation is insufficient to justify abstention except in "exceptional" circumstances. Colorado River, 424 U.S. at 816-17.

136. See, e.g., Littleton v. Fisher, 530 F.2d 691, 693 (6th Cir. 1976) (child custody proceedings); Kahn v. Shainswit, 414 F. Supp. 1064, 1068 (S.D.N.Y. 1976) (divorce proceedings).

137. See Kahn v. Shainswit, 414 F. Supp. 1064, $1067-68$ (S.D.N.Y. 1976) (Younger abstention warranted when divorce proceeding pending because doinestic relations matters predominantly of state concern). 
which a federal question is raised; instead this note argues that Younger principles demand restraint only in those actions in which federal review would interfere with a pending state court proceeding concerning a divorce, child custody, or alimony decree, or when a state decree is modifiable and federal review would effectively modify the decree, as opposed to determining its validity.

In Younger, the Court defined "comity" as

a proper respect for state functions, a recognition of the fact that the entire country is made up of a Union of separate state governments, and a continuance of the belief that the National Government will fare best if the States and their institutions are left free to perforn their separate functions in their separate ways. ${ }^{138}$

Principles of federalism, the Court found, coinmand "a system in which there is sensitivity to the legitimate interests of both State and National Government" so that when the federal government acts, it does so "in ways that will not unduly interfere with the legitimate activities of the states."139 Deternining whether federal review of a state court domestic relations decree impernissibly intrudes on legitimate state activity requires examination of those civil actions in which the Court has held Younger applicable.

Although the Supreme Court has specifically declined to extend Younger to all civil actions, ${ }^{140}$ in Huffman v. Pursue, Ltd. ${ }^{141}$ the Court applied Younger and refused to interfere with enforcement of a state civil nuisance statute. Although the Huffman Court emphasized the quasi-criminal nature of the statute, ${ }^{142}$ later Supreme Court decisions have inade it clear that Younger principles are not limited solely to such state civil proceedings "in aid of and closely related to criminal statutes." 143

In Juidice v. Vail 144 the Court held that Younger barred declaratory and injunctive relief in state civil contempt procedures. The Juidice Court relied particularly on the fact that the state's entire contempt process was at issue. ${ }^{145}$

138. Younger v. Harris, 401 U.S. at 44.

139. $I d$.

140. Moore v. Sims, 442 U.S. 415, 423 n.8 (1979); Trainor v. Hernandez, 431 U.S. 434, 445 n.8 (1977); Juidice v. Vail, 430 U.S. 327, 336 n.13 (1977); Huffman v. Pursue, Ltd., 420 U.S. 592, 607 (1975).

141. 420 U.S. 592 (1975).

142. Id. at $604-05$.

143. Trainor v. Hernandez, 431 U.S. 434 (1977); See Juidice v. Vail, 430 U.S. 327 (1977).

144. 430 U.S. 327 (1977).

145. The Juidice Court reasoned:

A State's interest in the contempt process, through which it vindicates the regular operation of its judicial system, so long as that system itself affords the opportunity to pursue federal claims withm it, is surely an inportant interest . . . . [W]e think the salient fact 
The Court also found the state concern important enough to justify abstention in Trainor $v$. Hernandez. ${ }^{146}$ In Trainor a state agency obtained a writ of attachment in a civil action to recoup welfare payinents which allegedly had been obtained fraudulently. The defendant then sought an injunction against the attachment. The Court held Younger applicable because "[b]oth the suit and the accompanying writ of attachment were brought to vindicate important state policies such as safeguarding the fiscal integrity of those programs."147

The crucial factors in the application of Younger equitable restraint to civil proceedings appear to be whether the state is a party in the action and the importance of the state's interest. ${ }^{148}$ The Supreme Court addressed the sufficiency of the state's interest in domestic relations in Moore v. Sims. ${ }^{149}$ In Moore a bare majority of the Court held that the Younger doctrine barred federal determination because of a pending proceeding brought by the state for temporary custody of children who allegedly had been abused. The Court disclaimed any intention to announce that Younger principles were applicable to all state civil proceedings ${ }^{150}$ and emphasized the compelling state interest in quickly removing child abuse victims from their parents. ${ }^{151}$ Moore, therefore, does not stand for the proposition that Younger equitable restraint is appropriate in every proceeding in which there is a pending state domestic relations action.

Lower courts have spht on whether Younger applies to most civil actions. ${ }^{152}$ Some federal courts have found Younger principles applicable to domestic relations actions and have deferred to pending state actions. ${ }^{153}$ These cases hold that even if a petitioner is not asking the

is that federal-court interference with the State's contempt process is "an offense to the State's interest . . . likely to be every bit as great as it would be were this a criminal proceeding."

430 U.S. $335-36$ (quoting Huffman, 420 U.S. at 604).

146. 431 U.S. 434 (1977).

147. Id. at 444.

148. See Trainor, 431 U.S. at 448 (Blackmun, J., concurring) ("The substantiality of the State's interest in its proceeding has been an important faetor in abstention cases under Younger v. Harris . . . from the beginning.").

149. 442 U.S. 415 (1979).

150. Id. at $423 \mathrm{n} .8$.

151. Id. at 435.

152. Compare Lanb Enters. v. Kiroff, 549 F.2d 1052, 1056 (6th Cir.), cert. denied, 431 U.S. 968 (1978) ("The same principles of federalism, equity and comity which underlie federal court reluctance to interfere in state crinimal proceedings apply with substantial force when the federal court is asked to enjoin state civil proceedings."), with O'Hair v. White, 675 F.2d 680, 695 (5th Cir. 1982) ("In those cases in which the Supreme Court has applied the Younger doctrine to civil litigation, the state was a party and, more importantly, was seeking to vindicate important state policies.").

153. See, e.g., Littleton v. Fisher, 530 F.2d 691 (6th Cir. 1976) (per curiam) (refused to grant imjunction in civil rights action with respect to proceeding in state doinestic relations case regard- 
federal court to enjoin state domestic relations proceedings, the court should abstain if the effect of federal review would be to bring the state proceedings to a halt ${ }^{154}$ or to nullify a state domestic relations decree. ${ }^{155}$ The requirement that federal courts abstain when review would halt state proceedings parallels Younger's command that state proceedings not be enjoined. But federal court abstention because federal review would effectively nullify a state court donnestic relations decree goes far beyond the policies underlying Younger equitable restraint.

In doinestic relations actions litigants are essentially asking the federal court to determine the validity of a decree. For example, in Williams v. Williams, ${ }^{156}$ the United States Court of Appeals for the Eighth Circuit found Younger principles applicable in an action seeking declaratory and injunctive relief agamst adoption proceedings that were used to sever appellant's legal relationship with his children. The court found that Younger principles barred declaratory and injunctive relief because such relief would nullify the state court adoption decree, which "relates to an area, domestic relations, which has traditionally been the province of the states." 157 But the Williams court failed to examine the reasons why domestic relations actions are within the provimce of the state and appears to imply that in any action involving domestic relations Younger equitable restraint is appropriate. The court was not asked to grant or inodify a custody decree, ${ }^{158}$ but to determine whether lack of notice in state proceedings severing parental rights violates the Constitution, and if so, to enjoin enforcement of a decree granted in constitutionally infirm proceedings. This question is not within the peculiar province of the state courts, and the court should not have abstamed under Younger principles.

Therefore, Younger equitable restraint is appropriate only when a federal court is asked to enjoin state doinestic relations proceedings, or when federal review would effectively halt these proceedings. The peculiar modifiable nature of doinestic relations decrees, however, presents another factor to be considered in determining whether equitable restraint is appropriate.

The Supreme Court has stated that the Younger doctrine is not

ing custody of minor child); Williams v. Williams, 532 F.2d 120 (8th Cir. 1975) (per curiam) (declaratory and injunctive relief denied because it would nullify decree of a Missouri court related to an area of domestic relations that has traditionally been province of states).

154. See Huynn Thi Anh v. Levi, 586 F.2d 625, 633 (6th Cir. 1978).

155. See Williams v. Wilhams, 532 F.2d 120, 122 (8th Cir. 1975) (per curiam).

156. 532 F.2d 120 (8th Cir. 1975) (per curiam).

157. Id. at 122 .

158. See supra note 11 and accompanying text. 
applicable absent a pending state court proceeding. ${ }^{159}$ A domestic relations action involving a inodifiable decree, however, may constitute an exception to this general rule. In Etlin v. Dalton ${ }^{160}$ a state court awarded custody of a minor child to petitioner's ex-wife and ordered the petitioner to pay child support. Petitioner then brought an action for monetary, injunctive, and declaratory relief, alleging constitutional violations arising from the custody and support award. The United States Court of Appeals for the Fourth Circuit lield that Younger equitable restraimt applied, because under the state statute "custody determinations and support orders may be subject to modification at any time," and therefore "custody proceedings are considered ongoing proceedings." 161

The Supreme Court denied certiorari in Etlin, but Justices White and Brennan dissented. Justice White protested that "the Court has never applied the Younger doctrine to a case where the State was not a party to the pending state proceedings," 162 and therefore the application of Younger to the case "represents a substantial broadening of the doctrine."163 Justice White found unpersuasive the Fourth Circuit's equation of a modifiable decree with an on-going or pending state court proceeding. Because under this theory the custody proceedings would never be final, Justice White found that the appellate court's reasoning imposed an exhaustion requirement on the petitioner before he could bring a section 1983 action, a result that the Court's Younger doctrine decisions lad not contemplated. Justice White recognized an exception to the rule that section 1983 does not require exhaustion when "standards of local law are woven into the case" whose resolution should precede consideration by a federal court, ${ }^{164}$ but asserted that if the case fell within the exception, the court should "refrain temporarily from exercismg its jurisdiction, but . . . should not dismiss the case."165

Given the strong state interest in awarding or nuodifymg a domestic relations decree, and the importance of local factors and institutions in this decision, the Younger doctrine counsels equitable restraint when a federal court plaintiff seeks what amounts to federal modification of a decree modifiable under state law. Younger does not counsel restraint where, as in Etlin, the petitioner asks only that the federal court enjoin enforcement of a constitutionally infirm decree.

159. Zablocki v. Redhail, 434 U.S. 374, 379 n.5 (1978).

160. 673 F.2d 1309 (4th Cir. 1981), cert. denied, 102 S. Ct. 3496 (1982).

161. Etlin, 673 F.2d at 1309.

162. Etlin v. Robb, 102 S. Ct. 3496, 3497 (1982) (White, J., dissenting).

163. Id. at 3498.

164. Id. (quoting McNeese v. Board of Education, 373 U.S. 668, 673 (1963)).

165. Etlin v. Robb, 102 S. Ct. at 3498. 


\section{CONCLUSION}

Courts should apply abstention principles to domestic relations actions both for consistency in the law and for adequate protection of the statutory grant of diversity jurisdition. Under Burford abstention, federal courts should abstain only if the case presents a state interest of substantial concern and either an issue of unsettled state law or a comprehensive administrative and judicial mechanism with which federal review would interfere. Younger equitable restraint is appropriate only if the case requires enjoining state domestic relations proceedings, effectively haltimg state proceedings, or modifying a domestic relations decree involving important local factors. 